\title{
Software for visualization and analysis of signals from devices for measurement of shape deviations
}

\author{
Oprogramowanie do wizualizacji i analizy sygnałów pomiarowych \\ z urządzeń do pomiaru odchyłek kształtu
}

\author{
MACIEJ SIENIKO \\ JULIA SKRZESZEWSKA \\ MARTA WIŚNIEWSKA*
}

\author{
DOI: https://doi.org/10.17814/mechanik.2017.11.173
}

\begin{abstract}
The software developed at the Institute of Metrology and Biomedical Engineering is presented, which can be used for comparative analysis of rotary profiles of mechanical elements measured with FMM. The distinguishing feature of the software amongst solutions offered by the machine manufacturers is the ability to compare profiles recorded applying different measuring machines and at different times. In addition, the software allows to estimate the impact of the most important components of measurement uncertainty. As a result, it can be successfully used to evaluate the wear of mechanical components, such as motor pistons.
\end{abstract}

KEYWORDS: form deviation measuring device, FMM software, cylindricity deviation, roundness deviation

Zaprezentowano oprogramowanie opracowane w Instytucie Metrologii i Inżynierii Biomedycznej, które może być wykorzystywane do analiz porównawczych profili obrotowych elementów mechanicznych mierzonych urządzeniami do pomiaru odchyłek kształtu (FMM). Cechą, która wyróżnia program na tle rozwiązań proponowanych przez producentów maszyn, jest możliwość porównywania profili zarejestrowanych z użyciem różnych maszyn pomiarowych $i$ w różnym czasie. Ponadto oprogramowanie umożliwia oszacowanie wpływu najważniejszych składowych niepewności pomiaru. W rezultacie może być z powodzeniem stosowane do oceny zużycia elementów mechanicznych, np. tłoków silników.

SŁOWA KLUCZOWE: urządzenie do pomiaru odchyłek kształtu, oprogramowanie urządzeń FMM, odchyłka walcowości, odchyłka okrągłości

The cylindrical parts play a crucial role in mechanical devices. They are widely used in permanent joints or for power transmission systems. The vast majority of such elements, i.e. cylinders or cones, have a constant curvature, whereas the local radii of the others, i.e. pistons, changes. The quality of manufacturing of these components is crucial for ensuring reliability of whole mechanical systems, cost of their maintenance or their impact on the natural environment. Therefore, it is not surprising that the geometrical requirements imposed on these parts, referring to both their dimensional accuracy and departures from their nominal form, are becoming more and more strict.

Measurement of variation in radius with a use of dedicated metrological equipment - form measuring machine - is the most common method for assessment of departure from nominal form and orientation of mechanical elements (roundness and cylindricity especially).

\footnotetext{
* Dr inż. Maciej Sieniło (sienilo@mchtr.pw.edu.pl), Julia Skrzeszewska (julka.skr@gmail.com), mgr inż. Marta Wiśniewska (martwisn@mchtr. pw.edu.pl) - Instytut Metrologii i Inżynierii Biomedycznej, Wydział Mechatroniki Politechniki Warszawskiej
}

However, some additional preparatory steps have to come before measurement of each mechanical part. Among these activities there are for example: centring and levelling of the measured object. Then, during a roundness deviation measurement a circumferential surface of the measured part is scanned. However, these are just angular radius variations, not local dimensions, i.e. radius, that are registered. Next, measurement data is processed by dedicated software and analysed. In effect, the operator gets information concerning form deviations of the measured element, for example roundness (RONt) or cylindricity (CYLt) parameters. Nevertheless, if the standard algorithms and procedures are applied, the local dimensions of the measured part are not calculated.

The form measuring machines can be divided in 2 groups, depending on the method of signal registration: analogue (equipped with a pen recorder) - which are no longer manufactured, and the digital ones (with a computerised data registration and analysis). The most important mechanical parts of FMM are outlined in fig. 1, where the machine with a rotating table is presented.

Thanks to computer use, the mundane interpreting measurement results by the instrument's operator has been replaced with the digital data processing. Due to the digitalisation that facilitates automatization of positioning, analysis of the measured profiles, filtration, harmonic analysis or exclusion of parts of the measured profiles, i.e. with discontinuities or dirt, the completely new generation of the FMMs has been developed $[1 \div 3]$.

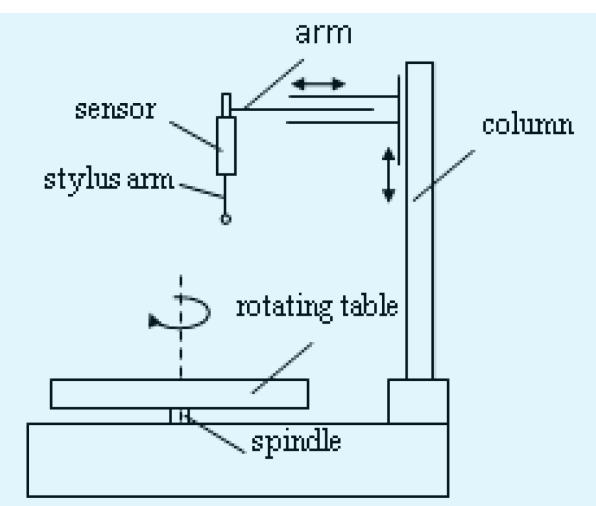

Fig. 1. Main components of the FMM equipped with a rotating table

\section{Commercial software of modern FMMs}

The leading global manufacturers of the FMMs, such as Taylor Hobson, Carl Zeiss, Mitutoyo or Mahr, have developed their own software dedicated to their instruments. However, the main functionalities of these systems are quite similar. Therefore, the authors decided to present such software, taking Ultra by Taylor Hobson as an 
example. This software works under Windows platform and is compatible with Talyrond machines. Not only does this program support signal transmission from the machine to the computer, but also it enables user to diagnose the machine, choose the measurement settings or analyse the obtained results. Among other capabilities given by Ultra there are: introducing rotation of a table to specified angular position or at demanded angle, the table displacement and tilting, contacting a stylus with measured surface. Also, this software is equipped with the algorithm of fully-automatized centring and levelling of the measured mechanical part. Among numerous functions of Ultra software there are as well: automatic exclusion of a part of signal, filtration and choice of the bandwidth to be excluded, choice of the reference element and selection of parameters to be calculated. Talyrond 365 may take an advantage of more than 20 parameters describing the measured profile quantitatively. The values of all estimated parameters may be exported to text files both manually and automatically, depending on the user's preferences. Finally, in the Ultra software a measurement procedure can be designed and repeated many times automatically, just after programming all steps of the measurement cycle.

In spite of the manufacturers' efforts to design comprehensive and universal software, their programs are not free of severe drawbacks. One of the disadvantages of these systems are not intuitive interfaces, lack or limited export of raw measurement data sets, limitations of the functions devised to automatize the measurement process. All these limitations are the more serious, the more complex and sophisticated measuring tasks are taken on. Also, these programs do not give opportunity to visualise, analyse and compare the results of different measurements, for example measurements of the same profile but made at different times. Such option would be an attractive solution for manufacturers of mechanical elements, as it would enable them to conduct efficient quality control and investigation of pace of their products' wear during exploitation. Then, necessary improvements of the manufacturing process could be implemented without unnecessary delays.

Due to lack of compatibility of measurement data file formats between the instruments devised by different manufacturers, or in extreme cases even when machines by the same producer considered, it is impossible to read and analyse measurement results obtained with numerous FMMs with a use of software delivered by the devices' makers. Therefore, comparing results becomes exceedingly difficult issue.

Another burning issue of form metrology seems to be the further development of numerical algorithms and software in order to equip them with an automatized system of calculating the measurement uncertainty. Nowadays, the measurement results are given without this value that is crucial for ensuring credibility of the obtained parameters. In result, machine's operator has to create the uncertainty budget and calculate the uncertainty himself, using the instrument's specification, his experience and usually making experimental research on his own just to assess an impact of factors that may affect the form deviation measurement results.

\section{Software dedicated to the FMM measurement results analysis}

Taking into consideration the limitations of widely used software that have been already listed, the authors gave a try and started working on the devising software, written in the MATLAB environment, which would be free of these drawbacks. The idea of the proposed program is based on the following assumptions:

- software can be used to analyse data from various FMMs, unless an export of the results from the program delivered by instrument's manufacturer to the text file is impossible,

- the measurement result is presented with its expanded uncertainty estimated using the most important components of the uncertainty budget,

- program gives an opportunity to compare and contrast profiles and form parameters of cylindrical elements which are measured at different times and with different form measuring machines applied to,

- the software calculates RONt and CYLt values automatically, ensures visualisation, filtration and spectral analysis of the measured profiles.

The basic version of the developed software (fig. 2) consists of 6 integrated modules. Each of them is saved in a separate file. The modules are as follows:

- data import and configuration module,

- reference element fitting module,

- data interpolation module,

- angular fitting module,

- filtration and spectral analysis module,

- visualisation and reporting module.

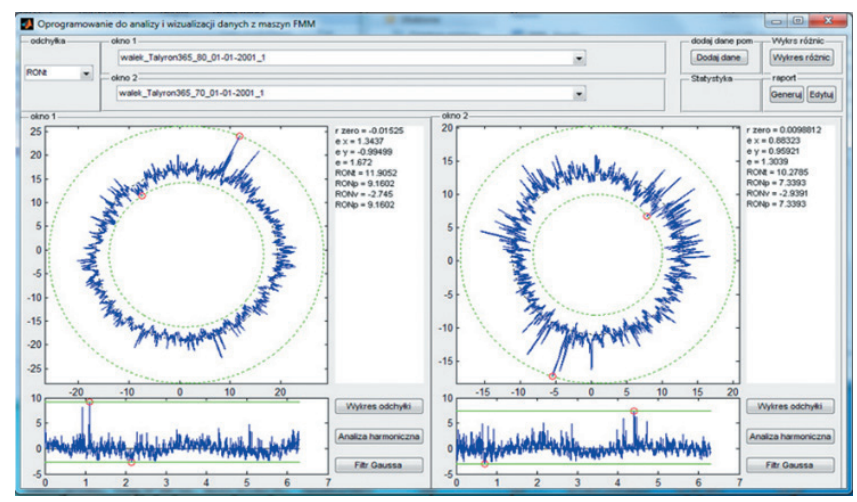

Fig. 2. Main window of the software

The data import and configuration module is used for choosing initial program parameters such as form measuring machine manufacturer and model, the measured element, paths of data files or setting the position of each analysed profile. This module can also be applied to define a number of the measured data points and their increased quantity after interpolation if it is required.

In the module algorithms and data analysis procedures are included as well. Also, data referring to metrological parameters of machines used in experimental researches is collected there. This data refers to i.e. inductive sensor characteristics and its nonlinearity or amplification coefficient, non-parallelism of spindle axis and column, column nonlinearity or spindle run-out. These parameters differ depending on the choice of form measuring machine and they may have a significant impact on the overall measurement uncertainty. They are applied, as well as information concerning eccentricity and non-levelling of the measured element, to estimate the measurement uncertainty values. Screen capture of data acquisition window is presented in fig. 3 .

The reference element fitting model enables user to calculate parameters of the element (line, circle or cylinder) fulfilling the least square (Gaussian) criterion. What 
is more, a sum of the maximum and absolute value of minimum local form deviations in order to calculate profile parameters, i.e. RONt. In order to do so, the widely used algorithms applicable to form measuring machines are used $[4,5]$. The measurement data interpolation module is used only if a number of points in the profiles under comparison differs. Then, it is unified with a use of spline interpolation.

The angular fitting module applies if the rotation of one of the compared profiles on another one is necessary in order to estimate roundness deviations from the reference element. Two fitting algorithms may be applied to do so. One of them bases on the phase difference between the same harmonics of both profiles. The other one is performed by using a cross-correlation function of the investigated profiles. Then, the angular difference between signals is transformed into a difference expressed in data points. Data points of one of the profiles are moved this distance in order to fit both signals.

The filtration and spectra analysis module is used to calculate phase and amplitude of profile harmonics. Then data may be filtered with a use of low-passing Gaussian filter. The filter bandwidth is selected by the software user.

Last but not least, the visualisation and reporting module generates the charts presenting the analysed profiles in the polar coordinates. Also, it is shows the differences between form deviations of the compared profiles. What is more, this module is responsible for illustrating cylindricity deviations and local differences between them if more than one profile is analysed. Then, the results of spectra analysis are presented graphically with a use of the algorithms implemented in this part of software. Finally, this module is reliable for producing reports from the measurements and exporting them to *.pdf files.

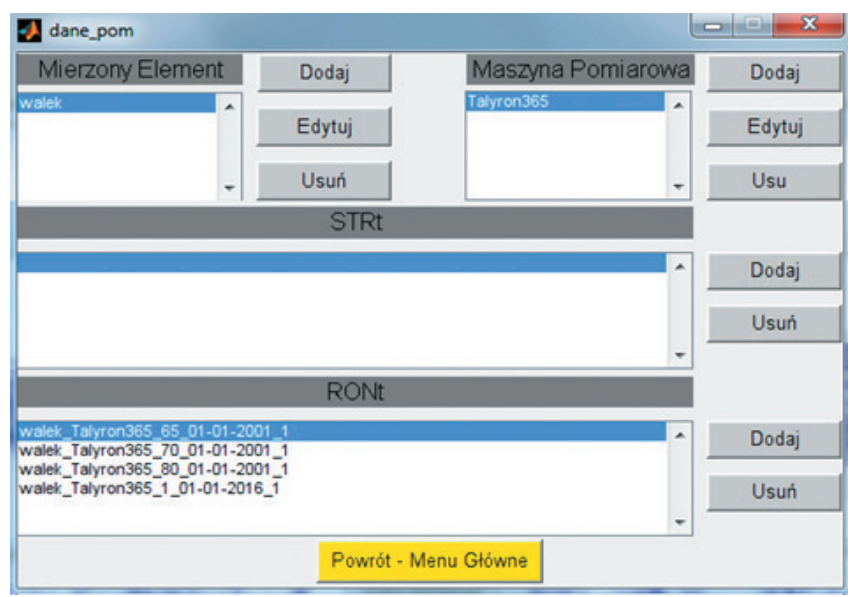

Fig. 3. Data import window

\section{The measurement uncertainty evaluation}

In the software there are the widely known algorithms of estimating an impact which the eccentricity and nonlevelling of the measured mechanical element have on the obtained results are implemented. These algorithms have already been presented in $[6,7]$.

What is more, according to the necessities of laboratories being a part of Institute of Metrology and Biomedical Engineering at Warsaw University of Technology, an influence of the crucial metrological properties of the FMMs being an equipment of the Institute on the measurement results has been evaluated. The instruments that have already been taken into consideration are Talyrond 200 and Talyrond 365, both by Taylor Hobson. When factors such as run-out, sensor's amplification or column's nonstraightness were analysed, the maximum values of errors have been estimated.

When an impact of sensor's characteristics nonlinearity or non-parallelism of spindle and column are thought through, the theoretical analysis has been performed and dependency of the expanded uncertainty on these factors is evaluated. However, it has to be outlined that the accurate estimation of an impact of sensor's nonlinearity requires determining this characteristics after each modification of measuring gauge, i.e. change of stylus or its angle. Then, the proper parameters can be imported to the program.

\section{Conclusion}

To sum up, capabilities of the proposed software are sufficient for determining form deviations of the measured mechanical elements. What is more, program enables user to estimate and take into consideration the measurement uncertainties that are specific for the measurement with a use of FMMs. The software may be developed and supplemented with further modules which may introduce i.e. other algorithms of reference element fitting, depending on the current needs being a result of the properties of measured elements. The authors are also going to implement other algorithms introducing corrections due to eccentricity and non-levelling of the measured part, spindle run-out or stylus tip shape. It is possible to add extra software functionalities such as advanced data analysis modules that would be applicable to profiles of elements with discontinuities, too. Introducing an option of excluding distorted parts of signal from analysis is worth to be done, as well.

Among the other improvements to be made there are:

- generating reports in other file formats, i.e. * .csv, * ${ }^{*}$.xlsx, - development of user's interface,

- introducing warnings and error alerts,

- integration of data from meteo station in order to assess impact of environmental conditions,

- introducing compatibility with CAD to automatically compare the results with the geometrical product specification.

Finally, the current version of software includes only the most important factors affecting the measurement uncertainty. The further development is required in order to obtain a comprehensive uncertainty budget.

The research was supported by the Institute of Metrology and Biomedical Engineering statutory funds (agreement no. 504/01747/1142).

\section{REFERENCES}

1 Rudziński R., Żebrowska-Łucyk S. et al. „Komputeryzacja analogowych przyrządów do pomiarów odchyłek kształtu". Praca Naukowa PW, seria Konferencja. II, 4 (1995): pp. 311-312.

2. Adamczak S. „Pomiary geometryczne powierzchni, zarysy kształtu, falistość i chropowatość". Warszawa: Wydawnictwa Naukowo-Techniczne, 2008.

3. Chen J.S., Ling C.C. "Improving the machine accuracy through machine tool metrology and error correction". The Int. J. of Adv. Manuf. Tech. 11, 3 (1996): pp. 198-205.

4. Żebrowska-Łucyk S. "Bezodniesieniowa metoda badania makrogeometrii powierzchni elementów obrotowych". Warszawa: Oficyna Wydawnicza Politechniki Warszawskiej, 2001.

5. Raja J., Muralikrishnan B. "Computional Surface and Roundness Metrology". London: Springer-Verlag, 2009.

6. Tomasik J. et al. „Sprawdzanie przyrządów do pomiaru długości i kąta". Warszawa: Oficyna Wydawnicza Politechniki Warszawskiej, 2003.

7. Arendarski J. „Niepewność pomiarów”. Warszawa: Oficyna Wydawnicza Politechniki Warszawskiej, 2006. 